\title{
Harness/container assembly for sport parachutes - A new concept
}

\author{
ADRIAN SALISTEAN \\ CLAUDIA NICULESCU
}

DOI: 10.35530/IT.069.03.1474

CONSTANTIN NITE

GEORGETA POPESCU

SABINA OLARU

\section{REZUMAT - ABSTRACT}

\section{Ansamblul ham/container pentru parașute sport - Un nou concept}

Lucrarea prezintă un nou concept de proiectare al ansamblului ham/container pentru parașute sport. Acest ansamblu poate fi folosit cu parașute de rezervă și parașute principale de diferite volume. Ansamblul va fi multifuncțional. Containerul este subansamblul care păstrează în cele două compartimente parașuta principală și parașuta de rezervă în stare pliată, împreună cu suspantele, dispozitivul de deschidere și parașuta extractoare. Hamul sau sistemul de suspensie asigură legătura dintre parașutist și voalură, susținand greutatea parașutistului.

În prezent, producătorii de containere pentru parașute sport realizează containere ale căror compartimente au un volum bine definit și sunt dedicate unui anumit tip de parașută cu același volum, în stare pliată, al compartimentului în care va fi introdusă.

Noul concept propune proiectarea și dezvoltarea unui ansamblu ham/container cu compartimente ce pot avea un volum variabil. Astfel este posibil să avem un container multifuncțional utilizabil cu voaluri de volume diferite în stare pliată. „Această lucrare a fost realizată prin Programul-nucleu, derulat cu sprijinul ANCSI, proiect nr. PN 16340301 ”

Cuvinte cheie: container (capotă), compartiment, volum, parașută principală, parașută de rezervă.

\section{Harness/container assembly for the sport parachute - A new concept}

The paper presents a new design concept of the harness/container assembly for sport parachutes. It can be used with reserve parachutes and main parachutes of different volumes. So the assembly will be multifunctional. The container is the subassembly that keeps the main and reserve parachute canopies in a folded condition, together with the suspensions lines, the deployment device and the pilot chute in the reserve and main compartments. The harness, or suspension system, ensures the link between the parachute jumper and the canopies and supports the weight of the parachute jumper.

Currently, container parachute manufacturers produce containers whose compartments have a well-defined volume and dedicated to a particular type of parachute with the same volume in folded state.

The new concept consists in the design and development of a harness/container assembly with variable volume compartments. Thus it is possible to have a multifunctional container usable with canopies of different volume in a folded state.

Keywords: container, compartment, volume, main parachute, reserve parachute

\section{INTRODUCTION}

The ham/container assembly is an individual equipment for parachutist, representing the parachutist's safety system, controlling the deployment and opening of the parachutes. The harness/container assembly includes all the parts necessary to make the parachute to be able to fly. The basic harness/container assembly is what remains when all detachable subassemblies (without sewing) are removed. The container is the subassembly that holds the main and reserve parachutes in a folded state together with the suspension lines, the deployment device, if used, and the pilot chute. Containers for sport parachutes have 2 compartments each for each type of parachute: main and reserve. The main parachute is connected to the bottom compartment and the reserve parachute is connected to the top compartment.

The harness (suspension system) is the subassembly consisting of webbings, which is designed to conform to the shape of the body, it makes the connection between parachutist and the canopy, supports the weight of the parachutist, ensures the safety of the parachutist at the parachute opening force and uniformly distributes the weight of the load during the opening and descent. The sport parachute assemblies have the harness and containers integrated into one assembly [1].

Currently, the dimensions of the container compartments are designed and manufactured in different sizes to accommodate with the folded volume of the canopies. For example, ICON containers are designed and manufactured in 9 sizes for 9 different volumes of the reserve parachute and 9 different volumes of the main parachute, both in folded state [2]. Quasar II containers are designed and manufactured for 9 different volumes of the reserve parachute in folded state and for each reserve parachute between 1 and 4 volumes of the main parachute in folded state [3]. The container must be rigid, molded on the body and 
small enough to be circumvented by the airflow and allow complete freedom of movement.

The reserve parachute compartment is generally smaller, close-fitting, and especially in a cone trunk shape. The design of the reserve compartment must be made in such a way that, in the event of an incident, the reserve opens quickly. Designing the reserve parachute compartment can be done in two ways: with the pilot chute inside the container or outside. The design of the main parachute compartment is less restrictive than that of the reserve parachute. The main parachute compartment is in the parallelepiped shape. It is preferable to design a container that does not matter the order of closing the flaps or one in which the flaps cannot be closed incorrectly.

Container compartments must include the parachute opening bags. In these bags are folded in the "Free Bag" state parachutes, that is, they are extracted from the pilot chute, fall freely above the parachutist and keep locked up until the complete deployment of the suspension lines. Only after the suspensions lines are deployment, allows the parachute to start the swelling process.

A parachute assembly, in conformity with AC 105-2D, normally but not exclusively, consists of the following major components: a canopy, a deployment device, a pilot chute and/or drogue, risers, a stowage container, a harness, and an actuation device (ripcord).

\section{EXPERIMENTAL WORK}

\section{Development of the harness/container assembly}

When designing the container we considered the requirement for the correct opening of the parachute when the ripcord, the static line and the pilot chute or the AAD (opening device of the reserve parachute) are activated and the uninterrupted unfolding of the canopy.

In the design and construction of the harness the following requirements were imposed: to be comfortable to wear; to fit all people between $150 \mathrm{~cm}$ and $200 \mathrm{~cm}$ and $50 \mathrm{~kg}$ to $120 \mathrm{~kg}$ weight with winter clothing; the ripcord device to operate quickly and safely at an effort of up to $10 \mathrm{~kg}$; body adjustments to be simple, visible and minimal; to support the body safely; the straps should not interfere with the flexible metal cable with any adjusting or automatic opening reinforcement button.

All assemblies and stitches have been designed to support the weight test.

The materials used in the manufacture of the assembly are standardized as parachute materials. In the assembly the main materials used were: 1000 denier Cordura fabric with $300 \mathrm{~g} / \mathrm{m}^{2}$, breaking strength of 300 daN and abrasion resistance of at least 50,000 cycles Martindale (MIL-C-43734, class 3) and for harness webbing with $43 \mathrm{~mm}$ width and 2700 daN breaking strength (PIA-W-4088).

Figure 1 shows the harness/container assembly developed and its subcomponents.

\section{Calculation of container compartments volume}

The aim of this research was to design and develop a harness/container multifunctional assembly with the variable volume compartments that can be used with reserve and main parachutes of different volumes and different types. More than 200 main canopies are available on the market, which implies an enormous challenge for container manufacturers about container size. Containers must be sized for

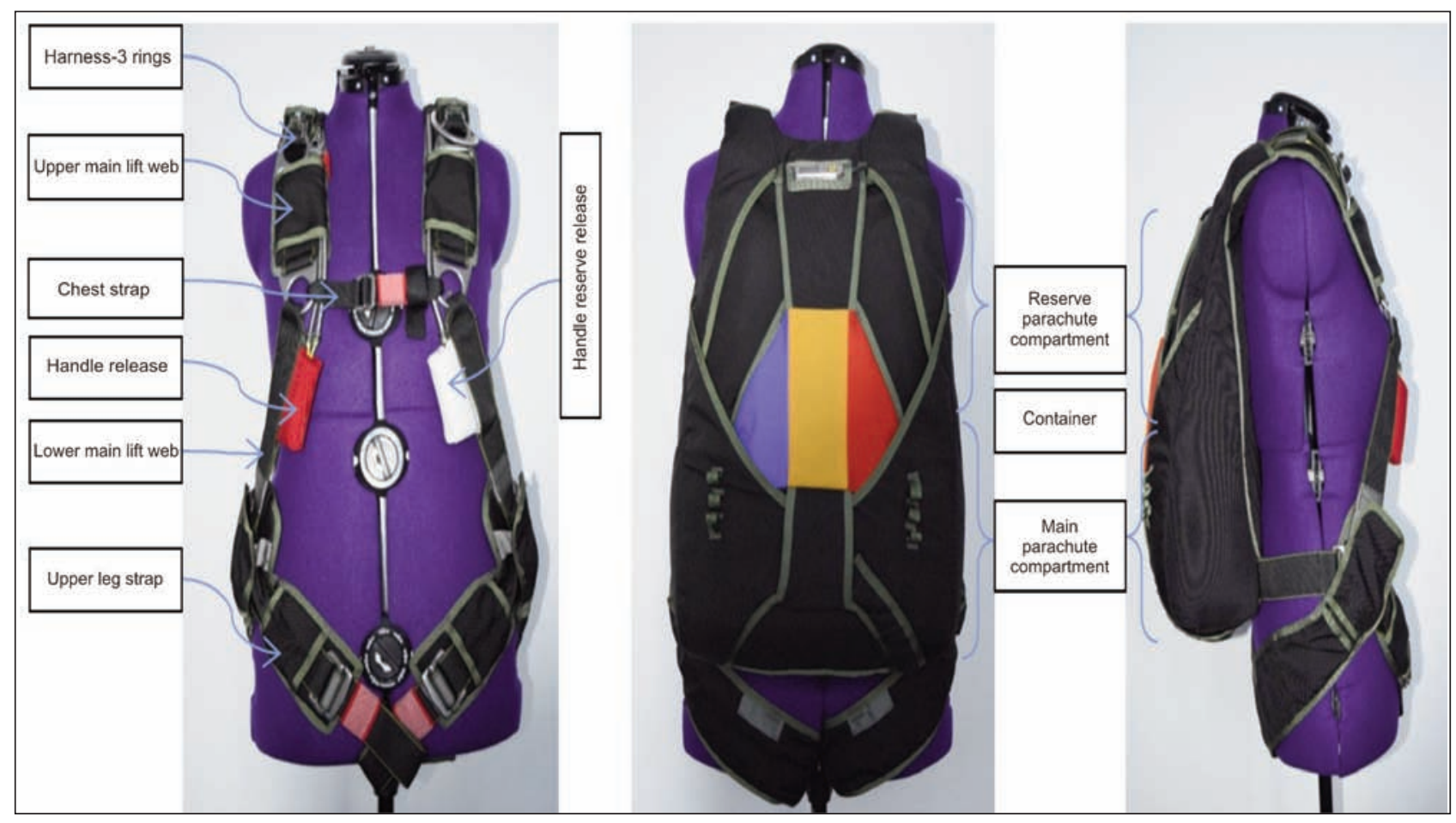

Fig. 1. The harness/container assembly and its subcomponents 


\begin{tabular}{|c|c|c|c|c|}
\hline \multicolumn{2}{|c|}{ Parachute type } & Producer & No. cells & Certified volume, $\mathbf{c m}^{\mathbf{3}}$ \\
\hline Reserve parachute & Swift 200 & PARA-FLITE & 5 & 6769 \\
\hline & Smart 220 & AERODYNE RESEARCH & 7 & 7572 \\
\hline & Smart 250 & AERODYNE RESEARCH & 7 & 7752 \\
\hline Main parachute & Skylark SK 190 & SKYLARK & 7 & 6785 \\
\hline & Solo 270 & AERODYNE RESEARCH & 9 & 8637 \\
\hline & Manta 290 & ZP MANTA & 9 & 9340 \\
\hline
\end{tabular}

the canopies that enter them. Over dimensioning and under dimensioning can cause problems. Oversize can cause faster stitching and eyelets, and undersize can lead to premature openings caused by pins entering loops that are too slightly loaded.

The volume of the deployment bags and, implicitly, of the compartments of the container shall be calculated as follows:

a) the rectangular bag of the main parachute

$$
A_{B} \cdot h
$$

b) the truncated cone bag of the reserve parachute

$$
h / 3\left(A_{B}+A_{b}\right)+\sqrt{ }\left(A_{B} \cdot A_{b}\right)
$$

where:

$A_{B}$ is the large base area of the parallelepiped or truncated cone;

$A_{b}$ - the small base of the truncated cone;

$h$ - the height of the parallelepiped and the truncated cone.

To achieve the proposed aim, the main parachute compartment was designed with the possibility of a variable $h$, and for the reserve parachute compartment the variation of the length of the reserve parachute closing loop. To be noted that the volumes of parachutes with the same surface, in the folded state, may vary depending on the type of canopy fabric and the type of the suspension lines. So, for the same surfaces $15.77 \mathrm{~m}^{3}$, different canopies have different volumes, e.g. $6,064 \mathrm{~cm}^{3}$ (Micron 175), 6,146 $\mathrm{cm}^{3}$ (Laser 5) and 6,425 $\mathrm{cm}^{3}$ (Bogy 178-R). The difference comes from the type of suspension lines, e.g. Kevlar (Micron 175), Dacron (Laser 5) and Spectra (Bogy 178-R) and from the fabric type (weight per square meter, air permeability, soft or stiff handling).

\section{Materials and volume testing method}

For the testing of the variable volumes of the multifunctional container we used reserve parachutes and main parachutes of different volumes, provided by the Romanian Air club. The volume of the parachute compartment was tested using Swift 200 [4], Smart 220 and Smart 250 [5], with manufacturer certified volumes. Skylark MA 190 [6], Solo 270 [7] and Manta 290 [8] were used as main parachutes.

The characteristics of the parachutes used in testing the volumes of the multifunctional container compartments are shown in table 1.

\section{RESULTS}

The container compartment for reserve parachute was closed correctly with all three types of parachutes that were tested. The length of the closing loop, figure 2, of reserve compartment for each type of reserve parachute is the following:

Swift 200 parachute: $10,5 \mathrm{~cm}$.

Smart 220 parachute: $12,5 \mathrm{~cm}$.

Smart 250 parachute: $14,5 \mathrm{~cm}$.

The handle command works correctly and the reserve parachute opens easily and correctly.

The container compartment for the main parachute was closed correctly with all three types of parachutes. The volume of the main compartment can be easily varied by using the extra volume from the created pocket.

At the flight testing the reserve parachute and the main parachute were correctly opened. There was no damage to the fabric and stitches of the container and harness.

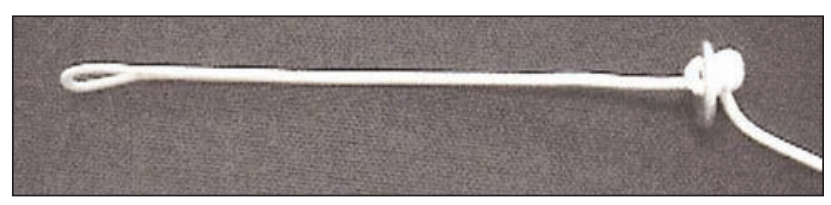

Fig. 2. The reserve closing loop

\section{CONCLUSIONS}

The new concept of the multifunctional container is functional. It allows:

- equipping with reserve parachutes of different types and with volumes within the limits $6769 \mathrm{~cm}^{3}$ minimum and $7752 \mathrm{~cm}^{3}$ maximum;

- equipping with main parachutes of different types and volumes within the limits $6785 \mathrm{~cm}^{3}$ minimum and $9340 \mathrm{~cm}^{3}$ maximum.

The advantage is quantified in the parachute clubs/ schools that purchase the multifunctional container that can be used with different parachutes in the endowment.

The proposed solution is patented pending.

\section{ACKNOWLEDGEMENTS}

This work was carried out through the NUCLEU Program, carried out with the support of ANCSI, project no. PN 1634 0301. 


\section{BIBLIOGRAPHY}

[1] U.S. Department of Transportation Federal Aviation Administration, In: Parachute Rigger Handbook, 2015, Chapter 2.

[2] “Aerodyne Systems", In: ICON Harness/Container Owners Manual, 2015.

[3] "Strong Enterprises", In: “Quasar II, Harness/Container assembly, 2000.

[4] http://www.ebay.ie/itm/SWIFT-5-cell-early-ram-air-reserve-para-flite-parachute-skydive-canopy-/181850193169

[5] https://www.flyaerodyne.com/canopies/smart/smart-specs/

[6] http://www.skylark.com.ua/

[7] https://www.flyaerodyne.com/canopies/solo/solo-specs/

[8] ttp://www.parasutler.com/backup/askeri_egitim.html

Authors:

\section{ADRIAN SALISTEAN ${ }^{1}$ \\ CLAUDIA NICULESCU 1 \\ GEORGETA POPESCU 1 \\ SABINA OLARU ${ }^{1}$ \\ CONSTANTIN NITE ${ }^{2}$}

${ }^{1}$ National R\&D Institute for Textiles and Leather Bucharest (INCDTP)

16, Lucretiu Patrascanu, 030508 Bucharest, Romania,

${ }^{2}$ S.C CONDOR S.A, Sos. Vergului nr. 57, cod 022447, Bucharest, Romania

e-mail: adrian.salistean@certex.ro; claudia.niculescu@certex.ro; georgeta.popescu@certex.ro;

sabina.olaru@certex.ro; florin.nite@condor-sa.ro

Corresponding author:

ADRIAN SALISTEAN

e-mail: adrian.salistean@certex.ro 